\title{
Nurmikasvien geneettinen tutkimus - haasteena timotei
}

\author{
Maria Erkkilä1), Pirjo Tanhuanpääa) ja Outi Manninen ${ }^{1)}$ \\ 1) MTT Biotekniikka- ja elintarviketutkimus, Kasvigenomiikka, Myllytie 1, 31600 Jokioinen, \\ etunimi.sukunimi@mtt.fi
}

\section{Tiivistelmä}

Bioteknisillä menetelmillä, kuten DNA-merkeillä, pystytään nopeuttamaan myös nurmikasvien jalostusta. Nurmikasveista tutkituimpia ovat raiheinät (Lolium) ja nadat (Festuca), joilla on diploidi perimä (kaksinkertainen kromosomisto). Tutkimuksen kannalta haasteellisempia ovat polyploidiset kasvit, koska niiden periytyminen on monimutkaisempaa. Tämän tutkimuksen kohteena oli timotei (Phleum pratense), joka on heksaploidi (kuusinkertainen kromosomisto) ja jonka periyttämistapa on vielä epäselvä. Tutkimuksen pitkän tähtäimen tavoitteena on tehostaa timotein lajikejalostusta siten, että viljelijöillä olisi tulevaisuudessa käytössään satoisa, talvenkestävä, kasvurytmiltään optimaalinen ja sulavuudeltaan korkeatasoinen timoteilajike. Yhtenä tavoitteena oli tuottaa timoteijalostajien käyttöön valintatyökaluiksi DNA-merkkejä, jotka liittyvät soluseinän sulavuuteen ja talvituhosienten kestävyyteen. Tutkimusmateriaalina käytettiin kahta Boreal Kasvinjalostuksessa tuotettua timoteijälkeläistöä. Toisessa jälkeläistössä vaihteli rehun sulavuus. Kandidaattigeenianalyysin avulla haettiin rehun sulavuuteen liittyvien geenien edullisia geenimuotoja eli alleeleita. Toinen jälkeläistö testattiin Typhula ishikariensis -talvituhosienenkestävyyden suhteen, johon liittyviä kromosomialueita etsittiin bulkkianalyysin avulla. Kummankaan em. analyysin käytöstä timoteillä ei ole aiempaa kokemusta. Löytyneet DNA-merkit selittivät vain pienen osan ominaisuuksissa havaitusta vaihtelusta, mikä ei ole yllättävää ottaen huomioon timotein heksaploidin ja heterotsygoottisen perimän. Kuitenkin edulliseen alleeliin liittyvää DNA-merkkiä on mahdollista käyttää valintatyökaluna lajikejalostuksessa. Projektissa selvitettyjen rehun sulavuuteen vaikuttavien timotein ligniinibiosynteesigeenien sekvenssit tallennettiin Geenipankin tietokantaan. Tämä on merkittävä lisä timotein geenitietoon, sillä aiemmat timoteisekvenssit geenipankeissa ovat lähinnä siitepölyallergeenien geenejä. Nyt päättyneen hankkeen materiaalia ja tuloksia voi jatkossa käyttää paitsi käytännön kasvinjalostustyössä myös kotimaisissa ja pohjoismaisessa nurmitutkimuksessa.

\section{Asiasanat}

DNA-merkit, rehun sulavuus, talvehtiminen, timotei 


\section{Johdanto}

Tutkimuksen pitkän tähtäimen tavoitteena on tehostaa timotein lajikejalostusta siten, että viljelijöillä olisi tulevaisuudessa käytössään satoisa, talvenkestävä, kasvurytmiltään optimaalinen ja sulavuudeltaan hyvä timoteilajike. Timotein tärkein jalostustavoite on satotason kohottaminen. Rehusato koostuu pääsadosta sekä niiton jälkeisestä jälkikasvusadosta. Erityisesti jälkikasvukyvyssä esiintyy suurta perinnöllistä vaihtelua. Monivuotisen timotein talvenkestävyyden parantaminen on tärkeällä sijalla jalostusohjelmissa. Talvenkestävyysvalinta tehdään perinteisesti kentällä. Tärkein yksittäinen jalostustavoite on mustapahkulasienen (Typhula ishikariensis) kestävyys. Talvenkestävyyden jalostusta vaikeuttaa jälkikasvukyvyn ja talvehtimiskyvyn välinen negatiivinen korrelaatio.

Kasvigenomiikka tarjoaa uudenlaisen näkökulman kasvin kehityksen kaikkiin vaiheisiin: itämiseen, erilaistumiseen, kasvuun ja stressin sietoon. Kasvigenomiikan kautta saatava tieto tulee suuresti muuttamaan kasvinjalostusprosesseja. Timotein DNA-tieto on kuitenkin vähäistä eikä sen geenien rakennetta tunneta tarkasti. Timotein perimärakennetta voidaan kuitenkin pyrkiä ymmärtämään muiden ns. mallilajien geenitietouden kautta. Tässä tutkimuksessa käytimme useita toisiaan täydentäviä bioteknisiä menetelmiä, kuten bulkkianalyysi (bulked segregant analysis), kandidaattigeenianalyysi sekä vertaileva genomiikka. Bulkkianalyysiä käytetään etsittäessä haluttuun ominaisuuteen liittyviä DNA-merkkejä. Kaksi bulkkinäytettä (esim. altis bulkki ja kestävä bulkki) muodostetaan yhdistämällä DNA:ta useammasta yksilöstä ominaisuusjakauman ääripäistä (esim. mahdollisimman alttiit ja kestävät yksilöt). DNA-merkki, joka esiintyy vain toisessa bulkissa, sijaitsee mahdollisesti lähellä ominaisuuteen vaikuttavaa geeniä ja analysoidaan koko jälkeläistössä tuloksen varmistamiseksi. Kandidaattigeenianalyysissä pyritään etsimään DNA-merkkejä geeneistä, jotka vaikuttavat tai joiden arvellaan vaikuttavan tutkittuun ominaisuuteen. Tässä tutkimuksessa haettiin eroavaisuuksia ligniinibiosynteesitien geeneistä cinnamyylialkoholidehydrogenaasi ja ortometyylitransferaasi, jotka vaikuttavat soluseinän rakenteeseen ja sitä kautta rehun sulavuuteen. Vertailevaa genomiikkaa käytettiin hyväksi suunnittelemalla alukkeet raiheinän ja nadan geenitietoon perustuen. Näillä alukkeilla saatiin vastaavat geenit monistettua timoteista.

Kasvigenomiikkatutkimuksen tavoitteena oli tuottaa timotein jalostajien käyttöön valintatyökaluiksi DNA-merkkejä, jotka liittyvät soluseinän sulavuuteen ja talvituhosienten kestävyyteen.

\section{Aineisto ja menetelmät}

Tutkimusmateriaalina käytettiin kahta aiemmin Boreal Kasvinjalostuksessa tuotettua timoteijälkeläistöä. Timoteiyksilöiden KAS8 ja KAS9 risteytysjälkeläisissä (laatujälkeläistö) vaihteli rehun sulavuus. Toinen jälkeläistö (risteytys Tammisto II $\mathrm{x}$ Nosappu) testattiin Typhulatalvituhosienenkestävyyden suhteen.

Kesällä 2006 kerättiin laatujälkeläistön ensimmäisestä sadosta näytteet tähkälle tulon aikaan (optimikorjuu) ja 10 päivää sen jälkeen (myöhästetty korjuu). Laatujälkeläistön jokaisesta jälkeläisestä määritettiin Boreal Kasvinjalostuksessa NIRS-tekniikan avulla useita rehulaatua kuvaavia arvoja [raakavalkuainen, kuitu (iNDF, NDF ja ADF), D-arvo]. Genotyypin vaikutus kaikkiin tutkittuihin ominaisuuksiin oli tilastollisesti erittäin merkitsevä $(\mathrm{P}<0.001)$ ja genotyyppi selitti $38-74 \%$ näytteiden välisestä vaihtelusta riippuen ominaisuudesta sekä siitä, oliko kyseessä lehti-, korsi- vai kokonaisnäyte.

Rehun sulavuuteen liittyviä DNA-merkkejä etsittiin kandidaattigeenianalyysin avulla. Kandidaattigeeneiksi valittiin ligniinibiosynteesitien geeneistä cinnamyylialkoholidehydrogenaasi ja ortometyylitransferaasi. Raiheinän ja nadan geenitietoa käytettiin hyväksi suunnittelemalla alukkeet omt- ja cad-geenien monistamiseksi timoteistä. Timotein geenit sekvenssoitiin käyttämällä Amersham Biosciences MegaBace-laitetta ja Sequencher-ohjelmaa. SNP (single nucleotide polymorphism) analysoinnissa käytettiin MegaBace SNP profiler -ohjelmaa yhdessä MegaBace SNuPe Genotyping kitin kanssa.

Timoteijälkeläistön Tammisto II x Nosappu tautitestaukset mustapahkulasienellä tehtiin MTT Rovaniemen tutkimusasemalla (Oiva Nissinen). Timoteijälkeläistö tartutettiin sekä sklerootioilla että sienisuspensiolla. Oraat havainnoitiin kolmesti. Havaintojen perusteella laskettiin kullekin jälkeläiselle taudinkestävyysindeksi, joka perustui sekä elossa olevien kasvien määrään että kasvien toipumisnopeuteen. 
DNA-analyysein haettiin Typhula- kestävyyteen ja rehun sulavuuteen liittyvien geenien edullisia geenimuotoja eli alleeleita. Typhula-kestävyyteen liittyvien merkkien etsinnässä käytettiin bulkkianalyysiä ja kestävyysindeksin perusteella valittiin kestävään ja alttiiseen bulkkiin tietyt kahdeksan yksilöä kumpaankin. DNA-merkkeinä käytettiin AFLP (amplified fragment length polymorphism), REMAP (retrotransposon-microsatellite amplified polymorphism), SRAP (sequencerelated amplified polymorphism) ja SSR (simple sequence repeat) -merkkejä. Merkkien liittyminen kestävyyteen testattiin t-testillä tai Mann Whitneyn U-testillä. Joinmap-ohjelmalla laskettiin DNAmerkkien väliset kytkennät ja NQTL-ohjelmalla paikallistettiin kestävyyteen liittyvä alue kytkentäryhmässä.

\section{Tulokset ja tulosten tarkastelu}

\section{DNA-merkkien kehittäminen rehun sulavuuteen}

Cinnamyylialkoholidehydrogenaasi ( cad) -geeni kloonattiin ja sekvenssoitiin vanhemmista KAS8 ja KAS9. Geenipankkiin tallennettiin KAS9:n genominen sekvenssi numerolla DQ358689. Sekvenssi on 1074 bp pitkä ja sisältää kolme eksonia sekä kaksi intronia. Verrattaessa timotein eksonisekvenssiä raiheinän (Lolium perenne) kolmeen mRNA-sekvenssiin nähdään, että timotein cad-geeni vastaa raiheinän cad1-geeniä. Vanhempien cad-geenisekvensseistä löydettiin 17 yhden emäksen eroavaisuutta eli SNP -kohtaa, joista 7:1lä testattiin koko jälkeläistö eli 86 yksilöä. SNP-kohdat ovat eksonissa, paitsi SNP6 on intronissa. Timoteiltä löysimme kaksi ortometyylitransferaasi (omt)-geeniä. Toinen vastaa raiheinän geeniä omt 1 sekä ruokonadan (Festuca arundinacea) geenejä comt $1 b$ ja $c$. Toinen löytämämme geeni on raiheinän $o m t 3$-geenin kaltainen. Geenipankkiin tallennettiin KAS8:n genominen sekvenssi (1330 bp) numerolla FJ211269. Vanhempien välillä löydettiin 16 SNP-kohtaa, joista 5:1lä testattiin koko jälkeläistö. Kehitetyt SNP-merkit eivät toimineet toivotulla tavalla. Kummastakaan geenistä ei kyetty löytämään yksittäistä SNP-eroa, jolla olisi kyetty identifioimaan tietty KAS8 tai KAS9 spesifinen alleeli. Opimme, että polyploidin kasvin kohdalla SNP-merkkien luotettava käyttö edellyttää genomispesifisten SNP-merkkien kehittämistä.

KAS8:n omt-geenin 3 kloonista löytyi poikkeavaa sekvenssiä verrattuna muihin KAS8 klooneihin. Kohdassa 250 bp on kaksi kertaa toistojakso GAA, mutta 3 poikkeavassa kloonissa vain kerran. Deleetio vaikuttaa todennäköisesti siten, että se poistaa aminohapon lysiini (AAG). Kapillaarielektroforeesissa KAS8:1la nähdään 249,5 ja 250,5 bp:n kokoiset monistustuotteet. KAS9 ei tee tämän kokoista tuotetta lainkaan. (Kuva 1.) Sulavuusjälkeläistön 18 jälkeläisellä 86:sta havaittiin KAS8:1le tyypillinen deleetio omt-geenissä. Deleetion ja laatuominaisuuksien välillä löytyi useita tilastollisesti merkitseviä yhteyksiä, mutta parhaimmillaankin selitysasteet jäivät alhaisiksi. Myöhästetyssä niitossa ko. DNA-fragmenttien esiintyminen selitti noin $9 \%$ lehtien sulavuudessa havaitusta vaihtelusta eli noin $12 \%$ ominaisuuden geneettisestä vaihtelusta. Timotein kuusinkertainen perimä todennäköisesti heikentää mahdollisuuksia löytää suurivaikutteisia alleeleita.

\section{DNA-merkit talvituhosientenkestävyydelle}

Typhula-kestävyysindeksin perusteella muodostetut kestävä ja altis bulkki testattiin yhteensä 139 AFLP-, 90 REMAP- ja 36 SRAP-alukeyhdistelmällä sekä 27 mikrosatelliitilla. Etsimme DNAmerkkejä, jotka monistuivat vain toisesta bulkista. Lupaavilta näyttävät alukeyhdistelmät testattiin useammassa jälkeläisessä. Seitsemän parasta DNA-merkkiä (5 AFLP:tä ja kaksi SRAPia) analysoitiin koko jälkeläistössä (164 kpl). Kuusi merkeistä liittyi Typhula-kestävyyteen ja kestävyyteen liittyvä merkki oli peräisin Tammisto II:lta, jonka kestävyys on parempi kuin Nosappu-vanhemman.

SRAP-merkit olivat kytkeytyneet vain toisiinsa, mutta AFLP:t muodostivat oman kytkentäryhmänsä, joka sisälsi Typhula-kestävyyteen vaikuttavan kromosomialueen. Lähin merkki sijaitsi $1.6 \mathrm{cM}: n$ päässä ominaisuuteen vaikuttavasta lokuksesta (QTL eli quantative trait locus, kuva 2.). QTL selittää $9 \%$ Typhula-kestävyyden vaihtelusta. 


\section{OMT}
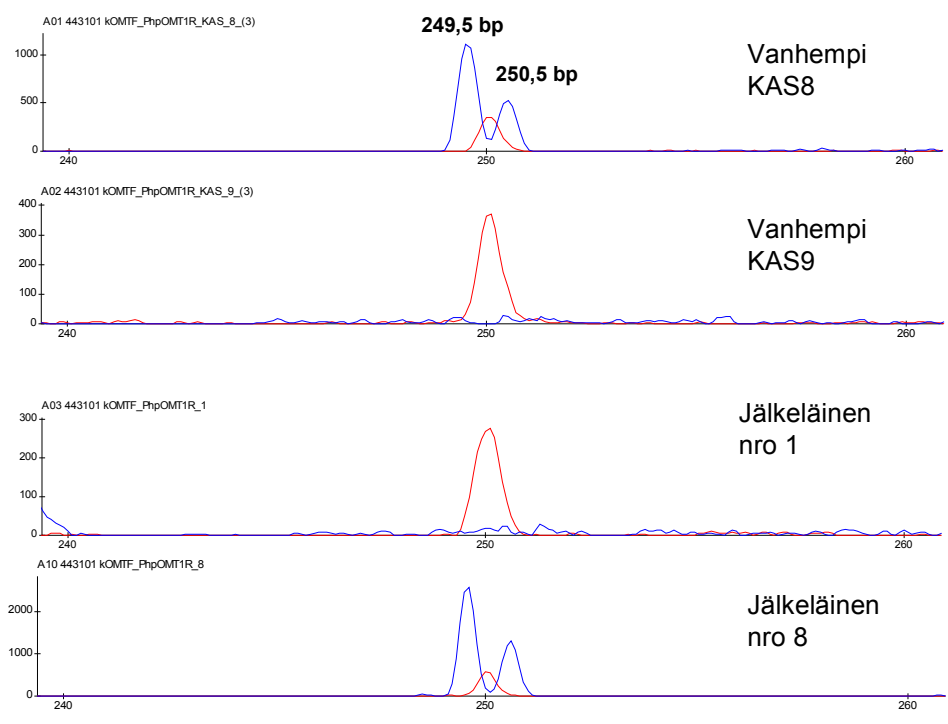

Kuva 1. Ortometyylitransferaasi-geenissä löytyvä ero risteytysvanhempien välillä sekä esimerkkinä kaksi jälkeläistä kapillaarielektroforeesiajossa. Sinisellä merkitty monistuva PCR-tuote, joka liittyy rehun sulavuuteen ja punaisella kokostandardi $250 \mathrm{bp}$.

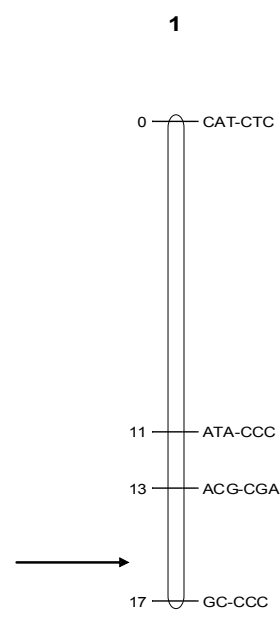

Kuva 2. Kytkentäryhmä sisältää talvituhosienten kestävyyteen vaikuttavan QTL:n, joka selittää ominaisuuksien vaihtelusta $9 \%$. Nuoli osoittaa QTL-kohdan.

\section{Johtopäätökset}

Löysimme timoteinjalostajille sulavuuteen ja Typhula-kestävyyteen liittyviä DNA-merkkejä. Typhulakestävyyteen liittyvät merkit löytyivät bulkkianalyysin avulla ja sulavuuteen liittyvät kandidaattigeenianalyysin avulla. Kummankaan menetelmän käytöstä timoteillä ei ole koko maailmassa aiempaa kokemusta. Löytyneet merkit eivät kuitenkaan selittäneet kovin merkittävää osaa ominaisuuksissa havaitusta vaihtelusta. Toisaalta timotein heksaploidin, heterotsygoottisen perimän huomioiden tämä ei ole kovin yllättävää. Projektissa selvitetyt timotein ligniinisynteesigeenien sekvenssit tallennettiin Geenipankin tietokantaan. Tämä on merkittävä lisä timotein geenitietoon, sillä aiemmat timoteisekvenssit geenipankeissa ovat lähinnä siitepölyallergeenien geenejä. Nyt päättyneen hankkeen materiaalia ja tuloksia voi jatkossa käyttää paitsi käytännön kasvinjalostustyössä myös kotimaisissa ja pohjoismaisessa nurmitutkimuksessa. 